\title{
Meta
}

Journal des traducteurs

Translators' Journal

\section{Interpretation as a Communicative Event: A Look through Hymes' Lenses}

\section{Claudia Angelelli}

Volume 45, numéro 4, décembre 2000

URI : https://id.erudit.org/iderudit/001891ar

DOI : https://doi.org/10.7202/001891ar

Aller au sommaire du numéro

\section{Éditeur(s)}

Les Presses de l'Université de Montréal

ISSN

0026-0452 (imprimé)

1492-1421 (numérique)

Découvrir la revue

Citer cet article

Angelelli, C. (2000). Interpretation as a Communicative Event: A Look through Hymes' Lenses. Meta, 45(4), 580-592. https://doi.org/10.7202/001891ar
Résumé de l'article

$\mathrm{Au}$ cours des dix dernières années, davantage de chercheurs et de praticiens se sont intéressés à l'interprétation en milieu social. Il s'agissait très souvent de voir quelles étaient les ressemblances et les différences entre cette forme d'interprétation et les autres, des problèmes de reconnaissance et de prestige se posant fréquemment. Toutefois, ce furent souvent les critères de l'interprétation de conférence qui furent appliqués à l'interprétation en milieu social et qui déterminèrent comment l'évaluer et l'enseigner. Ce transfert aveugle ne permettait évidemment pas de prendre pleinement conscience de l'énorme complexité de l'interprétation en milieu social. La présente recherche utilise la taxonomie de Hymes pour comparer et analyser deux interprétations, une en milieu social et l'autre lors d'une conférence, entre lesquelles notre analyse suggère qu'il y a plus de différences que de ressemblances.
Ce document est protégé par la loi sur le droit d'auteur. L’utilisation des services d’Érudit (y compris la reproduction) est assujettie à sa politique d'utilisation que vous pouvez consulter en ligne.

https://apropos.erudit.org/fr/usagers/politique-dutilisation/ 


\title{
Interpretation as a Communicative Event: A Look through Hymes' Lenses'
}

\author{
CLAUDIA ANGELELLI \\ Stanford University, United States of America
}

\begin{abstract}
RÉSUMÉ
Au cours des dix dernières années, davantage de chercheurs et de praticiens se sont intéressés à l'interprétation en milieu social. II s'agissait très souvent de voir quelles étaient les ressemblances et les différences entre cette forme d'interprétation et les autres, des problèmes de reconnaissance et de prestige se posant fréquemment. Toutefois, ce furent souvent les critères de l'interprétation de conférence qui furent appliqués à l'interprétation en milieu social et qui déterminèrent comment l'évaluer et l'enseigner. Ce transfert aveugle ne permettait évidemment pas de prendre pleinement conscience de l'énorme complexité de l'interprétation en milieu social. La présente recherche utilise la taxonomie de Hymes pour comparer et analyser deux interprétations, une en milieu social et l'autre lors d'une conférence, entre lesquelles notre analyse suggère qu'il y a plus de différences que de ressemblances.
\end{abstract}

\begin{abstract}
In the last ten years, more researchers and practitioners have turned their attention to community interpreting. Issues of similarities and differences with other forms of interpreting, as well as recognition and prestige, have arisen. It is often the case that the standards of conference interpreting are blindly transferred to other forms of interpreting both for measurement and educational purposes. This blind transfer does not allow a full understanding of the complexities involved in community interpreting. Hymes' taxonomy of speaking is used to compare and analyze two interpreting events, one occurring in a community setting and the other in a conference one. The analysis suggests that there are more differences than similarities between the two settings. The differences point to a complex form of social interaction which needs attention in its own right.
\end{abstract}

\section{MOTS-CLÉS/KEYWORDS}

communicative event, community and conference interpreting, ethnography of speaking, similarities and differences, norms of interaction and of interpretation

\section{Introduction}

Interpretation ${ }^{2}$ occurs during cross-cultural communication when two interlocutors do not share a language. The goal of translation or interpretation (T\&I) is that a message makes the same impact on the target audience that a speaker/signer intends for an audience of her/his same language. More often than not, the task of the interpreter is portrayed as one of "transcoding," a simple changing of one code (e.g. French, or ASL) to another (e.g. Spanish or American English). Is that enough to meet the goal of interpretation stated above? Probably not, since there is much more to communication than words or signs. Communication involves intention, context, form, gist, gesture, tone, relations of power, etc. The various and wide-ranging components 
of different situations where interpretation takes place make very different demands of the interpreter. A question we must consider is the following: How can we get a deeper understanding of interpretation that will allow us to meet the goals of communication in the different settings and contexts?

\section{Literature Review}

The current research on interpretation does not provide a comprehensive answer to this question. It has focused mainly on communication during conference interpretation (Gile 1983, 1988, 1991; Moser-Mercer 1994; Lambert 1989; Seleskovitch and Lederer 1989); emphasis has been given to the simultaneous mode over the consecutive one; and interpretation has mostly been viewed as a linear relationship between a speaker and a listener who do not share a linguistic code. The emphasis, however, has not been on interpretation as a social act; rather it has reflected a psycholinguistic and neurolinguistic approach to interpretation (except recently, for example, for Berk-Seligson 1990; Linell 1997; Kondo and Tebble 1997; Roy 1989 and 2000; Torsello 1997; Wadensjo 1996 and 1998). Discussion has been frequently limited to the question of linguistic codes and language or information processing.

Although limited to conference interpreting of oral languages, Seleskovitch and Lederer's work (1989) has been considered by the field of interpretation as one of the main pillars and classics since they were the first to write on interpretation and interpretation pedagogy. According to these authors, interpretation is the transfer of a message across languages. The interpreter's role is simply to decode and encode the message in such a way that the meaning and form may transfer into the language of the second party to produce the same effect that they would have produced in an audience who shared the first party's language.

Also from within the field of T\&I, Gile (1995: 21-27) argues for a communication model in translation and interpretation that includes the following components: 1) aim/intention (inform, explain, convince); 2) sender; 3) discourse (content and package); and 4) receiver. Gile's addition to Seleskovitch and Lederer's formula was the element of intention. Gile's "discourse (content and package)" equals the sum of "linguistic and extralinguistic component" suggested by his predecessors.

Although the research in conference interpreting is sparse at best, at present there is even less research on community interpreting. The similarities and differences between conference and community interpreting have barely been discussed and never empirically studied. In a recent presentation on this topic, Roberts posed the question "what's in a name?" and argued for the fact that "Interpreting is interpreting." Her argument was based on the similarities of community and conference interpreting in order for the former to achieve the same status and prestige that the later enjoys today. Roberts' analysis was based on a comparison of the following five elements: 1) the modes of interpreting (simultaneous, consecutive, short consecutive); 2) the modes of discourse (monologues and dialogues); 3 ) the discourse types (narrative, procedural); 4) the evaluation criteria (style of presentation, accuracy of content); and 5) the ethical principles (confidentiality, recognition of limits of expertise). She concluded that both types of interpretation were equal on the types of skills they required from interpreters and on the ethical principles they observed. For Roberts, "it would not make any sense to make distinctions according to settings and have 
separate training programs and code of ethics for each type of interpreting." In her opinion, "the real difference is the weight that each type of interpretation assigned to each category. For example, there is more dialogue in community interpreting since in conference interpreting it is generally limited to the period of questions and answers." (Roberts 1998).

Through numerous interviews I held with community interpreters I found some support for Robert's argument. In an attempt to be recognized and enjoy some of the prestige that conference interpreters enjoy today, community interpreter organizations, in fact, try to emulate conference interpreters in some way (e.g. assessment criteria for in-service trainees, guidelines, etc.) instead of establishing criteria based on their own needs. Therefore, often the standards of conference interpreting (both for instructional and measurement purposes) get transferred to other types of interpreting. However, if it can be shown that different interpretation situations are different in substantive ways (without falling into the prestige trap), a single standard of interpretation will be seen as inappropriate since different communicative events require different performances on the part of the interpreter. The analysis of similarities and differences will shed light on the complexities involved in community interpreting. By understanding the complexities involved, community interpreting should gain more recognition than it has at present.

In this paper, I will explore interpretation events where the standards of conference interpreting (regardless of prestige) may prove insufficient to gain an understanding of the complexity involved in community interpreting. For that purpose I will consider Hymes' theory of communication as a possible remedy to the gap left by interpretation research when trying to understand and explain interpretation as a communicative event. I will then describe two interpretation events observed in two different settings as part of a larger study ${ }^{3}$ and look at them through Hymes' lenses.

\section{Interpretation Situations as Communicative Events}

This section will focus on two interpretation situations: conference and community interpreting. My view is that these represent two points on an interpretation continuum, rather than a dichotomy. The rationale behind choosing to compare conference interpreting in a simultaneous mode (done in a booth) with community interpreting in consecutive mode is what emerges from the literature (see Introduction) and from the average situations observed.

A close look at the interaction of both community and conference interpretation situations shows that there are various important differences. What we now know may be limited to the following contrasts (based on higher frequency of occurences):

\begin{tabular}{|l|l|}
\hline Community Interpreting & Conference Interpreting \\
\hline Dialogic mode & Monologic mode (mostly) \\
\hline Equal amount of work into both languages & $\begin{array}{l}\text { Most of the work into one language } \\
\text { (interpreter's A language, generally) }\end{array}$ \\
\hline Possibility of controlling the traffic flow & $\begin{array}{l}\text { Unable to control the speaker } \\
\text { (except for requests to reduce speed when } \\
\text { equipment allows for it - speaker button) }\end{array}$ \\
\hline
\end{tabular}




\begin{tabular}{|l|l|}
\hline $\begin{array}{l}\text { Parties' participation in the communicative } \\
\text { event may not be optional } \\
\text { (e.g. in the case of a patient) }\end{array}$ & $\begin{array}{l}\text { Parties' participation in the communicative } \\
\text { event may be optional (e.g. in the case of a } \\
\text { member of the audience) }\end{array}$ \\
\hline $\begin{array}{l}\text { Maximum potential for different backgrounds } \\
\text { between the parties }\end{array}$ & $\begin{array}{l}\text { Minimum potential for different backgrounds } \\
\text { between the parties }\end{array}$ \\
\hline $\begin{array}{l}\text { Maximum potential for linguistic varieties } \\
\text { of the same code (in both languages) }\end{array}$ & $\begin{array}{l}\text { Minimum potential for linguistic varieties } \\
\text { of the same code (in only one language, } \\
\text { the speaker's) }\end{array}$ \\
\hline Maximum potential for different registers & Minimum potential for different registers \\
\hline
\end{tabular}

Hymes' framework for understanding a communicative event may offer a more complete and more complex characterization of the similarities and differences of these two interpreting events.

\section{Hymes' theory of communication}

Hymes' contribution to the field of communication is fundamental. He calls for an expansion of the scope of linguistics: an ethnography of communication that would study "communicative form and function in integral relation to each other" (Hymes 1974: 5). Hymes does not deny the importance of formal linguistics. Rather, he adds a new dimension to it so that communication might be considered as a whole. Hymes bases his ethnography of communication partly on the roots of linguistics (and formal linguistic) and partly on a general perspective of human behavior with roots in anthropology, sociology and psychology. He states that "the kind of linguistics that can contribute to the ethnography of communication is now generally known as sociolinguistics" (1974: 8). But, he carefully defines this term according to an ethnography of speaking in order to differentiate his focus from other concentrations that also fall under sociolinguistics. Examples of these are Labov's work on discrete phonetic units, or the interactionists' approach to sociolinguistics such as Schiffrin, Tannen, or Kasper (mainly for discourse analysis and conversational analysis).

For Hymes, sociolinguistics viewed from the standpoint of ethnography of speaking must be part of the study of communication as a whole. He states that a change in a number of orientations toward language is necessary for the contribution of the ethnography of speaking to be realized. He distinguishes the following seven orientations: 1) the structure, or system of speech (la parole); 2) function as prior to warranting structure; 3) language as organized in terms of a plurality of functions, the different functions themselves warranting different perspectives and organizations; 4) the appropriateness of linguistic elements and messages; 5) diversity of the functions of diverse languages and other communicative means; 6) the community or other social context as starting point of analysis and understanding; 7) functions themselves to be warranted in context, and in general the place, boundaries and organization of language and of other communicative means in a community to be taken as problematic (1974: 9). In short, primacy of speech to code, function to structure, and context to message.

Hymes suggests a taxonomy of speaking, whose natural unit of analysis is the 
speech community (1974: 35). He defines a speech community as "a social, rather than a linguistic entity" (1974: 47) thus differentiating it from language. This distinction separates Hymes 'work from Bloomfield's or Chomsky's since the later have equated speech community to language. Hymes' theory of speaking considers as fundamental the notions of ways of speaking, fluent speaker, speech community, speech situation, speech event, speech act, rules of speaking and function of speech (for definitions within the context of the interpretation events see IV 1 and 2). He also analyzes the following speech components (1974: 53-62):

1. message form: how something is said by members in a given speech community and according to the descriptive characteristics outlined above;

2. message content: topic and change of topic;

3. setting: the time and place of a speech act and, in general, the physical circumstances;

4. scene: the cultural definition of an occasion; the "psychological setting";

5. participants: may include the following: speaker, or sender; addressor; hearer, or receiver, or audience; addressee;

6. purposes - outcomes: the expected outcome of a speech event as recognized by the speech community;

7. purposes - goals: the intentions of participants and the strategies they define;

8. key: tone, manner, or spirit of a speech act (e.g. seriousness, sarcasm, etc.);

9. channels: the medium of speech transmission (e.g. oral, written, visual, etc.);

10. forms of speech: the different languages, dialects, varieties, and registers used in a speech event/act; may be joined with channels as means or agencies of speaking;

11. norms of interaction: rules governing speaking;

12. norms of interpretation: the belief system of a community and how that interacts with the frame of references for understanding utterances; and

13. genres: categories of speech (e.g. poem, myth, tale, proverb, riddle, curse, prayer, oration, lecture, etc.); though often coincidental with speech event, genres must be treated as analytically independent.

Hymes' approach to communication is comprehensive and complex. But does it help to understand the complexities of communication via interpretation?

\section{A "Hymesian" approach to interpretation}

From a larger corpus (400 interpretation events) which is part of a larger study in progress, I have selected two interpretation situations (community and conference) to focus on and discuss their fundamental notions. Then, Hymes' components of a communicative event will be discussed and applied to both situations in Table I.

The case selected for the analysis of Community Interpreting portrays a 36-year old female (Marcia $\left.{ }^{4}\right)$ interpreting for a middle-aged male Spanish Heritage speaker at the Office of Car Registration on the West Coast. The OCR officer, Caucasian middle-aged male, is trying to explain the forms that have to be completed in order to avoid further delays on a vehicle registration. The two interlocutors engaged in a cross-linguistic communication facilitated by the interpreter.

The case selected for the analysis of Conference Interpreting involves a middleaged Caucasian CEO of Engines, Inc. ${ }^{5}$ launching a new model during a press conference in the Great Lakes area. The audience is made up of 150 journalists, $65 \%$ male from around the US. There are 4 teams of interpreters serving French, Spanish, 
German and Portuguese audiences. The interpreter portrayed in this analysis is a middle-aged Caucasian male (Pierre ${ }^{6}$ ) hired by the Conference Organizers to work in the French booth. There are four language booths working in this conference: French, German, Japanese and English. The interpreters facilitate communication between the CEO and the audience.

\section{Community interpretation: an analysis of the fundamental notions of the communicative event according to Hymes}

We may assume that a community interpreter is probably quite familiar with the ways of speaking that occur in her/his community. Undoubtedly, this means that she/ he is a fluent speaker of that speech community. In the example of the interpretation event at OCR in Muirwood City, we cannot say that both interlocutors share a speech community. The speech community of Muirwood City residents may be totally different from the speech community of OCR officers. Marcia is a member of the speech community of Muirwood City residents but not of the OCR officers. The speech situation is the conversation between the Hispanic driver and the Caucasian OCR officer (both belonging to different speech communities) about a change in the registration of a motor vehicle. The speech event is an exchange during that interview (the officer explains the process to the driver); the speech act is a remark during that conversation (tone, irony, etc., e.g. the driver uses irony to express frustration about the unnecessary complexity of the process).

\section{Conference interpretation: an analysis of the fundamental notions of the communicative event according to Hymes}

A conference interpreter has to be familiar with the ways of speaking that occur in a conference. However, this does not necessarily mean that he/she must be a fluent speaker of that speech community (of which the speaker and the audience are genuine members who do not share a common language); Pierre is in fact a "temporary guest" of that community (as it is the case of most free-lance interpreters who constantly change from one speech community to another; for example, from glass production to automobile marketing). The exception may be the staff interpreters for organizations such as the UN or the IB, who have acquired an identity within those communities as co-speakers. If we follow the example of the automobile manufacturer (Engines, Inc. launching its new model at the International Automobile Fair in January '98), and we consider that a speech community (Automobile Marketing Experts, Automobile dealers and specialized press), the speech situation within it is the press conference launching this model. The speech event is a speech during that conference (the CEO responsible for Marketing shows the advantages of the model). The speech act is a remark during that speech (a joke-for example the CEO jokes about the potential buyers of the new model).

In Table I, I will illustrate how Hymes' components of speech (1974: 53-62) can serve as a framework to analyze those two interpretation events (the Engines, Inc. conference and the conversation at OCR in Muirwood City). 


\section{The components of communicative events according to $\mathrm{Hymes}^{7}$}

TABLE I

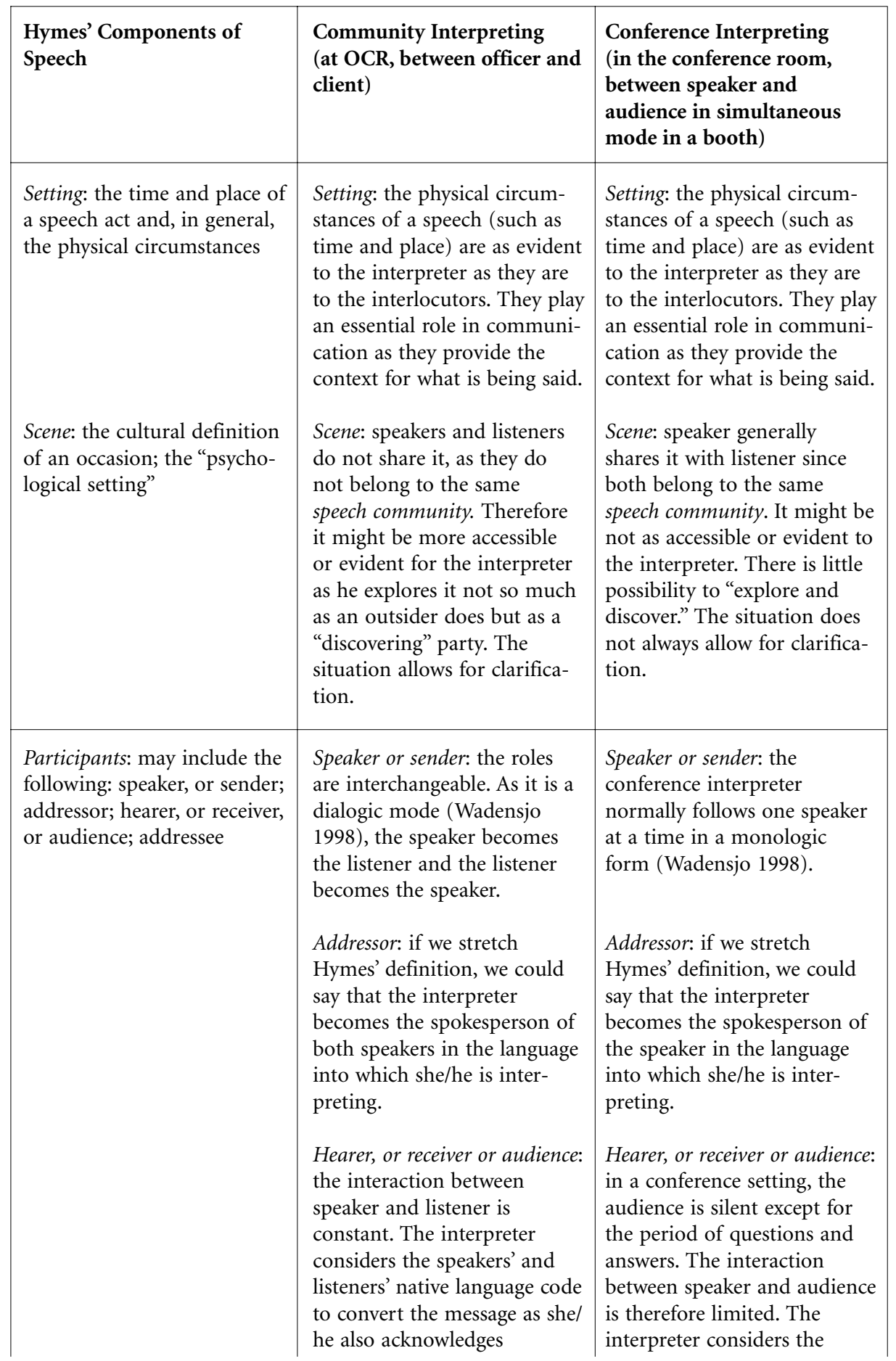




\begin{tabular}{|c|c|c|}
\hline & $\begin{array}{l}\text { Addressee: the interpreter } \\
\text { identifies the addressees in } \\
\text { each exchange, she/he is able } \\
\text { to see how the message and } \\
\text { event may be anticipated at } \\
\text { its destination (Is the officer } \\
\text { going to be surprised by a } \\
\text { tone? Is the driver going to } \\
\text { feel intimidated by the tone?) }\end{array}$ & $\begin{array}{l}\text { audience's native language } \\
\text { code to convert the message } \\
\text { (even when different linguis- } \\
\text { tic varieties cannot generally } \\
\text { be acknowledged or negoti- } \\
\text { ated). There is no dialogue } \\
\text { between the interpreter and } \\
\text { the audience at this market- } \\
\text { ing conference except for the } \\
\text { Q\&A period. } \\
\text { Addressee: when the inter- } \\
\text { preter identifies the address- } \\
\text { ees, she/he is able to see how } \\
\text { the message and event may be } \\
\text { anticipated at its destination. } \\
\text { (Are the sellers expecting this } \\
\text { new marketing campaign?) }\end{array}$ \\
\hline $\begin{array}{l}\text { Purposes-outcomes: the } \\
\text { expected outcome of a speech } \\
\text { event as recognized by the } \\
\text { speech community } \\
\text { Purposes-goals: the intentions } \\
\text { of participants and the } \\
\text { strategies they define }\end{array}$ & $\begin{array}{l}\text { Purposes - outcomes: the } \\
\text { interpreter cannot do the job } \\
\text { if she/he does not understand } \\
\text { what is the particular } \\
\text { outcome of the communica- } \\
\text { tive event. (Is it a decision to } \\
\text { renew a license, an intention } \\
\text { to extend a deadline to pay } \\
\text { registration?) There is room } \\
\text { for negotiation. } \\
\text { Purposes - goals: the inter- } \\
\text { preter will focus more on the } \\
\text { participant's intentions, on } \\
\text { their goals within the } \\
\text { outcome. (Who is making the } \\
\text { decision about the renewal? } \\
\text { Who will the decision affect } \\
\text { and how is that party } \\
\text { accommodating to the } \\
\text { making of that decision?). As } \\
\text { there is interaction, the } \\
\text { interpreter has the opportu- } \\
\text { nity to clarify. }\end{array}$ & $\begin{array}{l}\text { Purposes - outcomes: the } \\
\text { interpreter will benefit if he } \\
\text { understands what is the } \\
\text { particular outcome of the } \\
\text { communicative event. (Is it a } \\
\text { decision on a new model, a } \\
\text { legal ruling about some } \\
\text { sales?) There is almost no } \\
\text { room for negotiation. } \\
\text { Purposes - goals: the inter- } \\
\text { preter will focus more on the } \\
\text { participants' intentions, on } \\
\text { their goals within the } \\
\text { outcome. (Who is making the } \\
\text { decision about the new } \\
\text { model? Who will the decision } \\
\text { affect and how is that party } \\
\text { accommodating to the } \\
\text { making of that decision?) }\end{array}$ \\
\hline $\begin{array}{l}\text { Message form: how something } \\
\text { is said by members in a given } \\
\text { speech community and } \\
\text { according to the descriptive } \\
\text { characteristics outlined above }\end{array}$ & $\begin{array}{l}\text { Message form: the community } \\
\text { interpreter by virtue of being } \\
\text { a community member could } \\
\text { be familiar with how } \\
\text { members of that community } \\
\text { speak. She/he may or may not } \\
\text { be familiar with how OCR } \\
\text { officers speak to community } \\
\text { members who do not work }\end{array}$ & $\begin{array}{l}\text { Message form: "the more a } \\
\text { way of speaking has become } \\
\text { shared and meaningful within } \\
\text { a group the more likely that } \\
\text { crucial clues will be efficient" } \\
\text { (p. 55). It would be reason- } \\
\text { able to say then that the } \\
\text { interpreter should be aware of } \\
\text { the competence that speakers }\end{array}$ \\
\hline
\end{tabular}




\begin{tabular}{|c|c|c|}
\hline & $\begin{array}{l}\text { there (depending if she/he } \\
\text { even went through the same } \\
\text { experience herself/himself). } \\
\text { In this sense, she/he has an } \\
\text { advantage over the "tempo- } \\
\text { rary guest" at least for being } \\
\text { familiar with one of the } \\
\text { parties. }\end{array}$ & $\begin{array}{l}\text { of the automobile marketing } \\
\text { community have and share in } \\
\text { order to be able to go beyond } \\
\text { the content of an explicit } \\
\text { statement. But, is this } \\
\text { possible? Can a "temporary } \\
\text { guest" of a speech community } \\
\text { achieve this? How much time } \\
\text { does a "temporary guest" have } \\
\text { to spend within that commu- } \\
\text { nity in order to grasp the } \\
\text { ways of speaking of this speech } \\
\text { community? }\end{array}$ \\
\hline $\begin{array}{l}\text { Message content: topic and } \\
\text { change of topic }\end{array}$ & $\begin{array}{l}\text { Message content: the inter- } \\
\text { preter can follow a topic and } \\
\text { a change of topic by carefully } \\
\text { following the meaning of } \\
\text { what is being said. } \\
\text { Since the parties do not } \\
\text { necessarily share the same } \\
\text { communicative competence, } \\
\text { negotiation on the part of the } \\
\text { interpreter may be necessary. } \\
\text { The situation allows } \\
\text { negotiation. }\end{array}$ & $\begin{array}{l}\text { Message content: members of } \\
\text { the automobile marketing } \\
\text { group know what is being } \\
\text { said and when what is being } \\
\text { said has changed. Their } \\
\text { communicative competence } \\
\text { within the group allows them } \\
\text { to manage maintenance and } \\
\text { change of topic. Apparently, } \\
\text { the message content is more } \\
\text { concrete than the message } \\
\text { form and therefore might be } \\
\text { more accessible to a "tempo- } \\
\text { rary guest." The interpreter } \\
\text { can follow a topic and a } \\
\text { change of topic by carefully } \\
\text { following the meaning of } \\
\text { what is being said. }\end{array}$ \\
\hline $\begin{array}{l}\text { Key: tone, manner, or spirit } \\
\text { of a speech act (e.g. serious- } \\
\text { ness, sarcasm, etc.) }\end{array}$ & $\begin{array}{l}\text { Key: the interpreter will focus } \\
\text { on the tone, manner or spirit } \\
\text { of the each of the interlocu- } \\
\text { tors. }\end{array}$ & $\begin{array}{l}\text { Key: the interpreter will focus } \\
\text { on the tone, manner or spirit } \\
\text { of the speaker }\end{array}$ \\
\hline $\begin{array}{l}\text { Channels: the medium of } \\
\text { speech transmission (e.g. } \\
\text { oral, written, telegraphic, etc.) }\end{array}$ & $\begin{array}{l}\text { Channels: the interpreter has } \\
\text { only one input and that is } \\
\text { the oral channel. }\end{array}$ & $\begin{array}{l}\text { Channels: the interpreter may } \\
\text { have more than one input } \\
\text { since the oral channel may be } \\
\text { complemented by visual or } \\
\text { written modes projected on a } \\
\text { screen. }\end{array}$ \\
\hline $\begin{array}{l}\text { Forms of speech: the different } \\
\text { languages, dialects, varieties, } \\
\text { and registers used in a speech } \\
\text { event/act; may be joined } \\
\text { with channels as means or } \\
\text { agencies of speaking }\end{array}$ & $\begin{array}{l}\text { Forms of speech: the inter- } \\
\text { preter needs to be aware of } \\
\text { different registers, varieties, } \\
\text { etc. used by both the speaker } \\
\text { and the listener. The situation } \\
\text { allows for negotiation and } \\
\text { clarification. }\end{array}$ & $\begin{array}{l}\text { Forms of speech: the inter- } \\
\text { preter needs to be aware of } \\
\text { different registers, varieties, } \\
\text { etc. used by the speaker. } \\
\text { There is no room for } \\
\text { negotiation or clarification. }\end{array}$ \\
\hline $\begin{array}{l}\text { Norms of interaction: rules } \\
\text { governing speaking }\end{array}$ & $\begin{array}{l}\text { Norms of interaction: the } \\
\text { interpreter will see a wide } \\
\text { variety of interactions during }\end{array}$ & $\begin{array}{l}\text { Norms of interaction: the } \\
\text { interpreter will not see many } \\
\text { interactions during this }\end{array}$ \\
\hline
\end{tabular}




\begin{tabular}{|c|c|c|}
\hline & $\begin{array}{l}\text { this event. Often, the OCR } \\
\text { officer and the non-English } \\
\text { speaker (NES) do not share } \\
\text { the same sense of appropri- } \\
\text { ateness of ways of speaking. } \\
\text { For example, if the NES is } \\
\text { from Argentina, overlapping } \\
\text { will be the rule during a } \\
\text { conversation, while the officer } \\
\text { may expect turn-taking }\end{array}$ & $\begin{array}{l}\text { conference, except for the } \\
\text { period of questions and } \\
\text { answers. Generally, speaker } \\
\text { and audience share the same } \\
\text { sense of appropriateness of } \\
\text { asking and answering } \\
\text { questions in public. }\end{array}$ \\
\hline $\begin{array}{l}\text { Norms of interpretation: the } \\
\text { belief system of a community } \\
\text { and how that interacts with } \\
\text { the frame of references for } \\
\text { understanding utterances }\end{array}$ & $\begin{array}{l}\text { Norms of interpretation: } \\
\text { generally, the interpreter will } \\
\text { have a two-way focus on } \\
\text { interpretation of utterances. } \\
\text { He will be concerned about } \\
\text { how to portray the speaker in } \\
\text { a way that is acceptable to the } \\
\text { listener and vice-versa. If the } \\
\text { driver is a Korean, she/he will } \\
\text { probably not look the officer } \\
\text { in the eyes; if the officer is } \\
\text { not familiar with Korean } \\
\text { culture, he will probably be } \\
\text { suspicious. The interpreter } \\
\text { will need to be on the watch! }\end{array}$ & $\begin{array}{l}\text { Norms of interpretation: } \\
\text { generally, the interpreter will } \\
\text { have a one-way focus on } \\
\text { interpretation of utterances. } \\
\text { He will be concerned about } \\
\text { how to portray the speaker } \\
\text { in a way that is acceptable to } \\
\text { the interaction of the target } \\
\text { audience (again, the exception } \\
\text { being the period of questions } \\
\text { and answers when it will be a } \\
\text { two-way concern). }\end{array}$ \\
\hline $\begin{array}{l}\text { Genres: categories of speech } \\
\text { (e.g. poem, myth, tale, } \\
\text { proverb, riddle, curse, prayer, } \\
\text { oration, lecture, etc.); though } \\
\text { often coincidental with } \\
\text { speech events, genres must } \\
\text { be treated as analytically } \\
\text { independent }\end{array}$ & $\begin{array}{l}\text { Genres: the interpreter will } \\
\text { benefit from recognizing the } \\
\text { genre of the speech that does } \\
\text { not always coincide with the } \\
\text { event. For example, the officer } \\
\text { may lecture the community } \\
\text { member about a certain } \\
\text { occurrence but certainly the } \\
\text { event is not a lecture. }\end{array}$ & $\begin{array}{l}\text { Genres: the interpreter will } \\
\text { benefit from recognizing the } \\
\text { genre of the speech that does } \\
\text { not always coincide with the } \\
\text { event. For example, the } \\
\text { marketing expert may be } \\
\text { giving part of a sermon to } \\
\text { imitate a priest's advice to } \\
\text { use the new model Laville, } \\
\text { but he will most definitely } \\
\text { not be preaching. }\end{array}$ \\
\hline
\end{tabular}

\section{Discussion}

What do the contrasts from the table above tell us about the differences in interpretation tasks? Even when the differences are numerous, this discussion will concentrate only on the most salient ones:

Scene: Marcia could be able to discover or explore the "psychological settings" that the two parties may not share. The constant interaction with both speaker and listener allow for negotiation and clarification. On the other hand, Pierre may witness a situation in which speaker and listeners might share the scene (since they all belong to the same speech community), but there is little or no room to negotiate meaning with the speaker if needed.

Participants: Marcia is in constant interaction with both speaker and listener (whose roles are exchanged). She interprets for both parties as long as they participate 
in the speech event. As Marcia is facing a dialogic situation (of which she is an active participant too), she has the opportunity to interact differently if she needed to negotiate meaning (ask for elaboration, clarification, etc.). Pierre, on the other hand, has limited interaction with the speaker or the audience and only interprets for the speaker in a monologic mode.

Purposes-outcomes: the differences in setting may affect the interpretation (understanding) of the outcome. Marcia might be able to negotiate her/his interpretation of the outcome whereas Pierre does not have this opportunity.

Message form and content: Marcia is a member of the speech community of at least one of the parties (this is a significant difference from Pierre, the conference interpreter). During the interpretation act, as she tries to discover and explore the competence of the speaker with whom she is not familiar, Marcia has the opportunity to negotiate the message form and content. Pierre does not necessarily belong to the speech community that the speaker and the listener share; he would probably have better access to the content than to the form. The monologic mode does not allow much room for negotiation.

Forms of speech: Marcia is working with the speaker's and the listener's forms of speech, while Pierre is only focusing on the speaker's.

Norms of interaction and norms of interpretation: the community interpretation is a two-way interaction of three parties (speaker, listener and interpreter) who negotiate rules of interaction and interpretation (via the interpreter). During the conference where Pierre is interpreting, on the other hand, he follows a speaker in a one-way speech event. In this sense, the differences in norms of interaction and interpretation are minimal.

\section{Conclusion}

A Hymesian approach to an interpretation event and a Hymesian analysis of all its components allow a better and deeper understanding of similarities and differences across interpretation settings. It is only after we understand the complexity of a communication event that we can actually work within it (i.e. interpret it, in the case of the two examples studied above, or teach it, or assess it, etc.). Hymes' framework allows us to see that a single standard of interpretation is insufficient since the great difference in the situations, considered as communicative events, require different performances by the interpreter. Each of the interpretation settings described above calls not only for different abilities on the part of the interpreters (Marcia and Pierre) but also for a different understanding of the components of the communication act. By re-defining the interpretation situation as a communicative event and using Hymes' framework, we achieve a better understanding of the demands made of interpreters and how these differ in important ways depending on the context of the event.

Undoubtedly, a Hymesian approach to interpretation will have several implications both for the field of interpretation research and for pedagogy if we want to educate interpreters who can work in different settings at all levels of society. 


\section{ACKNOWLEDGEMENTS}

I want to express my appreciation to my colleague Jason Railey for his valuable suggestions on the first draft of this paper. I also want to thank two parties: the research participants whose insight was essential to this analysis and Christian Degueldre for the translation into French.

\section{NOTES}

1. The first version of this paper was presented at the 37th Congress of the Fédération Internationale des Traducteurs in Mons, Belgium, in August 1999.

2. Although the term translation has sometimes been used in the literature to refer to both interpreting and written translation, this work will treat them separately. For the purpose of this essay, interpretation is defined as the rendering of discourse spoken or signed in one language (source) into a spoken or signed form of another language (target).

3. During 28 months I surveyed, recorded and observed interpreters in conference, court, medical and community settings. Four hundred interpretation events form a pool of naturalistic data upon which this study draws.

4. Names have been changed to pseudonyms to protect the identity of research participants and of sites.

5. Idem.

6. Idem.

7. Adapted from Hymes 1964, 1974 and 1989.

\section{REFERENCES}

Berk-Seligson, S. (1990): The Bilingual Courtroom. Court Interpreters in the Judicial Process, Chicago, Chicago University Press.

Gile, D. (1983): «Aspects méthodologiques de l'évaluation de la qualité de travail en interprétation simultanée», Meta, 28-3, p. 236-243.

— (1988): «Le partage de l'attention et le modèle d'efforts en interprétation simultanée», The Interpreter's Newsletter, 1-4, p. 22.

- (1991): "The processing capacity issue in conference interpreting," Babel, 37-1, pp. 15-27.

- (1994): "Postcript," Conference Interpreting: Current Trends in Research. Proceedings of the International Conference on Interpreting: What do we know and how? (Turku, Finland. August 25-27, 1994) (Gambier, Gile and TaYlor, eds.), Amsterdam, John Benjamins Publishing, pp. 207-211.

GiLes, D. (1995): Basic Concepts and Models for Interpreter and Translator Training, Amsterdam, John Benjamins Publishing.

Hymes, D. (1964): “Introduction: toward ethnographies of communication," American Anthropologist, 66-2, pp. 12-25.

- (1974): Foundations in Sociolinguistics. An Ethnographic Approach, Philadelphia, University of Pennsylvania Press.

- (1989): "Ways of speaking," Explorations in the ethnography of speaking (R. Bauman and J. Sherzer, eds.), 2nd ed., Cambridge, Cambridge University Press, pp. 433-452.

Kondo, M. and H. Teвble (1997): "Intercultural communication, negotiation and interpreting," Conference Interpreting: Current Trends in Research. Proceedings of the International Conference on Interpreting: What do we know and how? (Turku, Finland. August 25-27, 1994) (Gambier, Gile and Taylor, eds.), Amsterdam, John Benjamins Publishing, pp. 149-166.

LAmbert, S. (1989): «La formation de l'interprète: la méthode cognitive», Meta, 34-4, p. 736-744. Linell, P. (1997): “Interpreting as communication," Conference Interpreting: Current Trends in Research. Proceedings of the International Conference on Interpreting: What do we know and how? (Turku, Finland. August 25-27, 1994) (GAmbier, Gile and TAYlor, eds.), Amsterdam, John Benjamins Publishing, pp. 49-67.

Moser-Mercer, B. (1994): "Aptitude testing in conference interpreting: why, when and how," Bridging the Gap: Empirical Research in Simultaneous Interpretation (S. LAMBERT and B. Moser-Mercer, eds.), Amsterdam, John Benjamins Publishing. 
RoBerts, R. (1998): What's in a name? Interpreting is interpreting, paper presented at the 39th American Translators Association Annual Conference in Hilton Head (SC), November, 1998.

Roy, C. (1989): A Sociolinguistic Analysis of the Interpreter's Role in the Turn Exchanges of an Interpreted Event, dissertation, Georgetown University, Washington (DC).

- (2000): Interpreting as a Discourse Process, New York, Oxford University Press.

Seleskovitch, D. et M. Lederer (1989): Pédagogie raisonnée de l'interprétation, Bruxelles, Didier Érudition, coll. «Traductologie», $\mathrm{n}^{\circ} 4$.

Torsello, C. (1997): "Linguistics, Discourse analysis and interpretation," Conference Interpreting: Current Trends in Research. Proceedings of the International Conference on Interpreting: What do we know and how? (Turku, Finland. August 25-27, 1994) (Gambier, Gile and Taylor, eds.), Amsterdam, John Benjamins Publishing, pp. 167-186).

WAdEnsjo, C. (1998): Interpreting as Interaction, New York, Addison Wesley Longman. 